\title{
Determination of Triazines in Hemodialysis Saline Solutions by Adsorptive Stripping Voltammetry after Extraction in Acetonitrile
}

\author{
Paulo Cícero do Nascimento*, Denise Bohrer, Leandro M. de Carvalho, Joselito Trevisan, \\ Eduardo Jorge Pilau, Zilda B. Vendrame and Morgana B. Dessuy
}

Departamento de Química, Universidade Federal de Santa Maria, 97110-970 Santa Maria-RS, Brasil

\begin{abstract}
A determinação de herbicidas 2-metiltio-4,6-dialquilamino-1,3,5-triazina (triazinas) em soluções salinas utilizadas em hemodiálise foi investigada por voltametria. Os herbicidas foram detectados com grande sensibilidade nas soluções salinas, após extração em fase de acetonitrila (ACN), utilizando o eletrodo de mercúrio de gota pendente. O efeito de salting out originado pelo meio salino existente nas soluções viabilizou as extrações. A relação de volumes entre as fases salina e de ACN foi investigada para alcançar a melhor sensibilidade na detecção das triazinas. A especiação entre as triazinas investigadas (ametrina, desmetrina, prometrina e terbutrina) não foi possível e recuperações entre 88 e $107 \%$ foram calculadas em amostras fortificadas com os analitos. Utilizando esta metodologia, limites de detecção de $0,03 \mu \mathrm{mol} \mathrm{L^{-1 }}$ foram calculados para as triazinas nas amostras salinas.
\end{abstract}

A method for the voltammetric determination of 2-methylthio-4,6-dialkylamino-1,3,5-triazine (triazines) herbicides in hemodialysis (HD) saline solutions was developed. The herbicides were detected in the saline solutions at the hanging mercury drop electrode (HMDE) with high sensitivities only after extraction of the analytes in acetonitrile (ACN). The salting out effect originated by the saline environment existing in the solutions enabled the extractions. The volume ratio between the saline and ACN phases was investigated in order to find the best sensitivity to detect the triazines. The speciation amongst them (ametryn, desmetryn, prometryn and terbutryn) was not possible. Recoveries between 88 and $107 \%$ were calculated in spiked samples, and detection limits of $0.03 \mu \mathrm{mol} \mathrm{L}{ }^{-1}$ were calculated for the triazines in the saline samples using this methodology.

Keywords: herbicides, triazines, hemodialysis, voltammetry

\section{Introduction}

The growing interest in the use of pesticides in agricultural production and their negative environmental impact has led to a number of studies for the development of different analytical methods. Besides the frequently used chromatographic measurements, voltammetry, mainly with differential pulse modes ${ }^{1-9}$ should be taken into consideration as a fast, easy and inexpensive alternative. Additionally, the sensitivity of the electrochemical methods, their applicability over an unusually wide concentration range, is highly satisfactory for meeting requirements of toxicological, ecotoxicological and environmental regulation enforcement. ${ }^{10}$

Hemodialysis (HD) solutions are prepared by mixing

*e-mail: npaulo@quimica.ufsm.br Dedicated to Prof. Dr. Georg Schwedt (TU Clausthal-Germany) on the occasion of his $60^{\text {th }}$ birthday. pure water and a high-salt (HS) content solution (about $7.0 \mathrm{~mol} \mathrm{~L}^{-1}$ ) to compose the final HD solution that has a salt concentration of about $0.2 \mathrm{~mol} \mathrm{~L}^{-1}$. It is used to maintain the blood ionic equilibrium of the patients during the hemodialysis sessions. The presence of contaminants in the water or in HS solutions must be detected before a hemodialysis session as the HD solution remains very close to the blood of the patients separated only by the dialysis membranes. To aggravate the problem, the dialysis membranes can dialysate many toxic substances, as hemodialysis is frequently the procedure adopted in the treatment of patients with acute intoxication symptoms. Additionally, for the chronic renal patients intoxication during a hemodialysis session can make the things still worse as the patients are not able to eliminate the toxins due to the inadequate renal function.

The WHO recommends to the quality control of HD solutions that free and combined chlorine and some metallic species must be detected at low concentration 
levels only in the water used to prepare the HD solution. Relatively to the HS solutions used to make the HD solutions there is only recommendations to use high purity solutions. In spite of the importance to control the quality of the HD or HS solutions there is an apparent lack of methods to assay contaminants in these solutions.

Although there is a number of methods employed to assay pesticides using different detectors as fluorimetric, ${ }^{11-17}$ photometric $^{18-20}$ and electrochemical, ${ }^{21-23}$ some problems still arise associated with the complexity of the matrices, particularly in the case of HS solutions where the ionic strength is so high that the common methods frequently fail. To overcome this difficulty, large dilution factors are often used but with prejudice to the sensitivity of the methods.

In this paper a methodology to assay some triazine herbicides, that are very persistent in soils and water, by adsorptive stripping voltammetry in HD or HS solutions was investigated. Although saline solutions normally are not a problem to voltammetric measurements, in the present case they also showed a negative influence (mainly in HS solutions) on the adsorption process of the analytes on the mercury electrode surface. The extraction of the triazines in acetonitrile enabled the determinations in HS solutions.

\section{Experimental}

\section{Instrumentation and apparatus}

Stripping measurements were made on a Metrohm 693 VA Processor in combination with a 694 VA-Stand operating at the hanging mercury drop electrode (HMDE) mode measurement. A preconcentration time of $30 \mathrm{~s}$ at $-800 \mathrm{mV}$ was used and the voltammograms were recorded in the potential range between -800 and $-1200 \mathrm{mV}$. Alternating current $(\mathrm{AC})$ voltammetric measurements were performed using an AC amplitude of $20 \mathrm{mV}$, a frequency of $60 \mathrm{~Hz}$ and a phase angle $\varphi=0^{\circ}$. A platinum wire was taken as the auxiliary electrode and all potentials were quoted against an $\mathrm{Ag} / \mathrm{AgCl}, \mathrm{KCl} 3 \mathrm{~mol} \mathrm{~L}^{-1}$ reference electrode. The cell volume was $10 \mathrm{~mL}$.

\section{Reagents and solutions}

Aqueous stock solutions of ametryn $\left(0.220 \mathrm{mmol} \mathrm{L}^{-1}\right)$, desmetryn (0.370 $\left.\mathrm{mmol} \mathrm{L}^{-1}\right)$, prometryn $\left(0.091 \mathrm{mmol} \mathrm{L}^{-1}\right)$ and terbutryn $\left(0.082 \mathrm{mmol} \mathrm{L}^{-1}\right)$ were prepared by weighing the triazines (Riedel-de Haën, Hannover, Germany) and dissolving them in pure water with 10 min manual vigorous agitation followed by 10 min sonication with a commercial ultra-sound batch (Sonorex, RK 510 H, Berlin). The obtained solutions were stable for long periods ( $>60$ days) without phase separation. The work solutions were prepared prior to use by dilution with water of the stock ones.

Deaerated background electrolyte (obtained by bubling for $10 \mathrm{~min}$ with nitrogen) were $\mathrm{HCl}$-water solutions in a concentration level enough to keep the voltammetric cell solution at $\mathrm{pH}$ 3.0.

Artificial HS solution containing $\mathrm{K}^{+}, \mathrm{Ca}^{2+}, \mathrm{Mg}^{2+}, \mathrm{Na}^{+}$ ions in a total concentration of about $7.0 \mathrm{~mol} \mathrm{~L}^{-1}$ were prepared from their chloride salts (all Merck). Glucose and $\mathrm{NaHCO}_{3}$ or $\mathrm{KHCO}_{3}$ were also used to compose some HS solutions. The commercial HS solutions had the following composition: Concentrate I: Solurin (JP Indústrias Farmacêuticas, São Paulo-Brazil) with 684.82 g (11.71 mol) $\mathrm{NaCl} ; 598.94 \mathrm{~g}$ (7.30 mol) $\mathrm{CH}_{3} \mathrm{COONa} ; 18.06 \mathrm{~g}(0.19)$ $\mathrm{MgCl}_{2}, 23.10 \mathrm{~g}(0.21 \mathrm{~mol}) \mathrm{CaCl}_{2}$ and $108.00 \mathrm{~g}(0.60 \mathrm{~mol})$ of glucose in $3.4 \mathrm{~L}$; Concentrate III: HB Bic (Salbego) with $947.6 \mathrm{~g}(16.20 \mathrm{~mol}) \mathrm{NaCl} ; 18.0 \mathrm{~g}(0.24 \mathrm{~mol}) \mathrm{KCl}$; $12.4 \mathrm{~g}(0.13 \mathrm{~mol}) \mathrm{MgCl}_{2}, 46.8 \mathrm{~g}(0.42 \mathrm{~mol}) \mathrm{CaCl}_{2}$ and $352.8 \mathrm{~g}$ (4.20 mol) of $\mathrm{NaHCO}_{3}$ in $4.0 \mathrm{~L}$; Concentrate IV: HD 3,5 (B. Braun, São Paulo-Brazil) with $864.40 \mathrm{~g}$ (14.78 mol) $\mathrm{NaCl} ; 13.41 \mathrm{~g}(0.18 \mathrm{~mol}) \mathrm{KCl} ; 6.27 \mathrm{~g}(0.07 \mathrm{~mol})$ $\mathrm{MgCl}_{2}, 23.10 \mathrm{~g}(0.21 \mathrm{~mol}) \mathrm{CaCl}_{2}, 352.8 \mathrm{~g}$ (4.20 mol) $\mathrm{NaHCO}_{3}$ and $108.00 \mathrm{~g}(0.60 \mathrm{~mol})$ of glucose in $3.4 \mathrm{~L}$.

\section{Analytical procedure}

$5 \mathrm{~mL}$ aliquots of $\mathrm{HS}$ solutions were added to a polyethylene flask and mixed with $3 \mathrm{~mL}$ of ACN. The flask was closed hermetically, and shaking moderately for $1 \mathrm{~min}$ was sufficient for the phase separation. A waiting time of 2 min was enough to the dissipation of the small water droplets present in the organic phase. A $2.0 \mathrm{~mL}$ aliquot of the ACN supernatant phase was carefully separated with a pipette and introduced in the voltammetric cell containing $8 \mathrm{~mL}$ of the $\mathrm{HCl}$-water background electrolyte solution ( $\mathrm{pH} 3$ ) previously deaerated. At the end of the accumulation period in stirred solution (2095 revolutions $\mathrm{min}^{-1}$ ), the stirrer was switched off and the voltammogram was recorded after $15 \mathrm{~s}$ had elapsed to allow the solution to become quiescent. All measurements were carried out at laboratory temperature $\left(24 \pm 2{ }^{\circ} \mathrm{C}\right)$. To assay the analytes in HD solutions, $7.6 \mathrm{mmol}$ of ammonium sulfate was added to the samples to assure the ACN phase separation.

\section{Results and Discussion}

\section{Extraction of triazine herbicides from HD solutions}

The solubility of triazines was investigated in two groups 
of organic solvents according to their dieletric constants $\left(\epsilon_{\mathrm{r}}\right){ }^{24}$ Group 1 comprised solvents with low polarity as hexane $\left(\epsilon_{\mathrm{r}}=1.89\right)$, tetrachloromethane $\left(\epsilon_{\mathrm{r}}=2.24\right)$, benzene $\left(\epsilon_{\mathrm{r}}=2.28\right)$, chloroform $\left(\in_{\mathrm{r}}=4.81\right)$, ethyl acetate $\left(\epsilon_{\mathrm{r}}=6.02\right)$, tetrahydrofuran $\left(\epsilon_{\mathrm{r}}=7.58\right)$, and dichloromethane $\left(\epsilon_{\mathrm{r}}=8.93\right)$. Group 2 the most polar ones as n-pentanol $\left(\epsilon_{\mathrm{r}}=13.90\right)$, nbutanol $\left(\epsilon_{\mathrm{r}}=17.80\right)$, acetone $\left(\epsilon_{\mathrm{r}}=20.56\right)$, ethanol $\left(\epsilon_{\mathrm{r}}=24.55\right)$, methanol $\left(\epsilon_{\mathrm{r}}=32.66\right)$, acetonitrile $\left(\epsilon_{\mathrm{r}}=35.9\right)$ and water $\left(\epsilon_{\mathrm{r}}=78.30\right)$. The triazines were more soluble in the solvents of the group 2 than group 1 , so that the solubility followed roughly the polarity of the solvent up to the ACN where the highest solubility was observed. Substituting the organic solvents by water a strong decrease on the solubility was observed suggesting that it matches the polarity of the solvent until a certain limit.

It is well known that $\mathrm{ACN}$ is quite soluble in pure water, but we observed a sudden decrease on its solubility as the saline concentration in water was increased. This way, in the HS solutions used in the hemodialysis procedures, only a small fraction $(15 \% \mathrm{v} / \mathrm{v})$ of ACN remains dissolved when the phase volume ratio (water/ACN) is 5:3 (Table 1). The salting out effect was responsible for the phase separation and besides the total saline concentration, a specific influence of some ions was also observed. Amongst the investigated species, ammonium sulfate was the only one that mixed with the HD or HS solution assured a full phase separation (100\%). However, in order to extract the triazines from the HS solutions, it was not necessary to add ammonium sulfate, because concentrations of triazines up to $6.3 \mu \mathrm{mol} \mathrm{L^{-1 }}$ were completely transferred from the aqueous to the ACN phase, even when $15 \%(\mathrm{v} / \mathrm{v})$ of the $\mathrm{ACN}$ remain dissolved in the aqueous phase. Table 1 shows the phase separation performances obtained by varying the volumes of the aqueous phases and their saline compositions. Keeping the ACN volume constant $(3.0 \mathrm{~mL})$ it was observed that the higher the aqueous phase volume the lower the ACN phase volume, so that high pre- concentration factors could not be obtained. The aqueous phase samples were prepared by dissolving the main ionic species encountered in HS solutions in order to have ionic strengths and volumes in crescent order. Additionally, five solutions were also prepared with only one ionic species. After the extraction as described in the experimental part, the volume of the $\mathrm{ACN}$ phase was measured. By using in the water phase only one ionic species $\left(\mathrm{NaCl}, \mathrm{KCl}, \mathrm{CaCl}_{2}\right.$ or $\mathrm{MgCl}_{2}$ ) even with high ionic strength, the phase separation was not well performed except in the presence of ammonium sulfate where an ionic strength of 2.26 was still enough for a complete phase separation.

\section{Adsorption of triazine on the mercury electrode}

Some herbicides containing triazine rings were already quantified in soils, ${ }^{25-27}$ plants $^{28-30}$ and water ${ }^{31-36}$ by voltammetry using, in most of the cases, mercury as working electrode. The electrode reaction of 1,3,5-triazine compounds depends primarily on the species located at the 2-position on the triazine ring (which is a thiomethyl group for some triazines), so that other substituents linked to the ring in different triazines are too far from the electroactive centre (2-position) and no pronounced effect on the peak potentials was expected. Indeed, the speciation amongst ametryn, desmetryn, prometryn and terbutryn by voltammetry was not possible.

The reaction pathways for the 1,3,5-triazines on the polarized mercury electrode can encompass two steps involving two electrons each or only one step involving four electrons. If the substituent $\mathrm{X}$ in the 2-position is chloro, ${ }^{37}$ hydroxyl ${ }^{37}$ or phosphorodithioate ${ }^{38}$ two steps pathway occur and two separated peaks can be obtained. In this case, the two-electron reduction of the $\mathrm{C}-\mathrm{X}$ bond precedes the two-electron reduction of $\mathrm{C}=\mathrm{N}$ bond in the triazinic ring. However, for the triazines where the substituent $\mathrm{X}$ is a thiomethyl group ${ }^{39}$ the one step pathway

Table 1. Phase separation of acetonitrile and water in presence of ionic species

\begin{tabular}{ccccc}
\hline Volume/mL & $\begin{array}{c}\text { Aqueous phase } \\
\text { Composition }\end{array}$ & $\begin{array}{c}\text { Ionic Strength } \\
(\mathrm{mol} \mathrm{L}-1)\end{array}$ & Acetonitrile (mL) & Phase separation $(\%)$ \\
\hline 5.0 & $\mathrm{Na}^{+}, \mathrm{K}^{+}, \mathrm{Mg}^{2+}, \mathrm{Ca}^{2+}, \mathrm{Cl}^{-}$ & 0.17 & 3.0 & 85 \\
10.0 & $\mathrm{Na}^{+}, \mathrm{K}^{+}, \mathrm{Mg}^{2+}, \mathrm{Ca}^{2+}, \mathrm{Cl}^{-}$ & 0.34 & 3.0 & 40 \\
20.0 & $\mathrm{Na}^{+}, \mathrm{K}^{+}, \mathrm{Mg}^{2+}, \mathrm{Ca}^{2+}, \mathrm{Cl}^{-}$ & 0.68 & 3.0 & 10 \\
50.0 & $\mathrm{Na}^{+}, \mathrm{K}^{+}, \mathrm{Mg}^{2+}, \mathrm{Ca}^{2+}, \mathrm{Cl}^{-}$ & 1.70 & 3.0 & 0 \\
100.0 & $\mathrm{Na}^{+}, \mathrm{K}^{+}, \mathrm{Mg}^{2+}, \mathrm{Ca}^{2+}, \mathrm{Cl}^{-}$ & 3.40 & 3.0 & 100 \\
5.0 & $\mathrm{NH}_{4}^{+}, \mathrm{SO}_{4}^{2-}$ & 2.26 & 3.0 & 60 \\
5.0 & $\mathrm{Na}^{+}, \mathrm{Cl}^{-}$ & 3.40 & 3.0 & 55 \\
5.0 & $\mathrm{~K}^{+}, \mathrm{Cl}^{-}$ & 3.40 & 3.0 & 64 \\
5.0 & $\mathrm{Mg}^{2+}, \mathrm{Cl}^{-}$ & 3.40 & 3.0 & 68 \\
\hline
\end{tabular}

Main composition of HS solution: $\mathrm{Na}^{+}, \mathrm{K}^{+}, \mathrm{Mg}^{2+}, \mathrm{Ca}^{2+}, \mathrm{Cl}^{-}$. 
explains better the single peak potential at $-950 \mathrm{mV}$ obtained for the triazines (ametryn, desmetryn, prometryn and terbutryn) investigated in this work. Additionally, no significant differences amongst the peak heights were observed for the triazines assayed individually in $\mathrm{HCl}-$ water solutions with the accumulation potentials ranging from 0 to $-800 \mathrm{mV}$ at fixed concentration and accumulation time. The affinity between mercury (HMDE) and the sulfur atom present in the triazines seems to be strong enough to assure the adsorption with only a moderate influence of the accumulation potential, although electrocapillary studies pointed out for some triazines the potential range from -400 to $-900 \mathrm{mV}$ as the most adequate one for their adsorptions on the HMDE. ${ }^{40}$ We adopted $-800 \mathrm{mV}$ as the accumulation potential. In this work, alternating current (AC) voltammetric measurements were used to confirm the potential range where the adsorption of triazines on the mercury electrode takes place. In AC voltammetric measurements, adsorption characteristic peaks can be produced at potentials where the adsorption or desorption occurs. In the potential region where the substance is adsorbed on the electrode surface, a depression in the capacity of the double layer is observed and this depression becomes larger with increasing concentrations up to saturation of the electrode surface. ${ }^{41,42}$

The AC voltammograms in Figure 1A shows that ametryn gives a characteristic desorption peak at $-950 \mathrm{mV}$, which was shifted towards more negative potentials as the concentration was increased. The evidence of the adsorption phenomena on the HMDE surface was the decrease in the capacity of the double layer observed in the potential range of -400 to $-900 \mathrm{mV}$ related to the increase of ametryn concentration.

The decrease in the capacity of the double layer was also observed for ametryn in water-ACN solution (Figure 1B). Therefore, in water-ACN solution, ametryn was also adsorbed on the mercury electrode as the characteristic nonfaradaic process was observed. A similar adsorption behavior in AC voltammetric measurements was also observed for the others triazines, desmetryn, prometryn and terbutryn, investigated in this work.

\section{Voltammetry of triazines in HS solutions}

The adsorptive accumulation of the triazines was significantly dependent on the composition of the solutions with respect to their saline concentration. Increases on the drop sizes were associated with high peak currents mainly for high ametryn concentrations, but limiting values in the peak currents were observed for concentrations higher than $2.19 \mu \mathrm{mol} \mathrm{L}^{-1}$ measured in $\mathrm{HCl}-$ water, $\mathrm{HCl}-\mathrm{HD}$ and $\mathrm{HCl}-\mathrm{HS}$
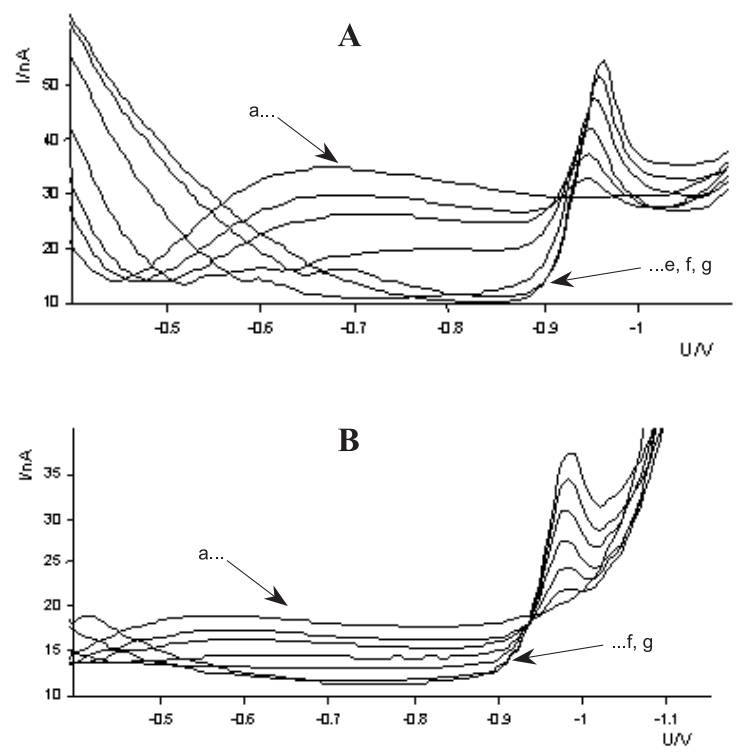

Figure 1. AC voltammetric measurements for ametryn in $\mathrm{A}$ ) aqueous and B) $20 \%$ (v/v) ACN solution: (a) 0, (b) 0.44, (c) 0.88, (d) 1.76 , (e) 2.64 , (f) 3.52 and (g) $5.28 \mu \mathrm{mol} \mathrm{L}^{-1}$ ametryn; conditions: $\mathrm{HCl} 10^{-3} \mathrm{~mol} \mathrm{~L}^{-1}$ as supporting electrolyte, $\mathrm{U}_{\text {mod }}=20 \mathrm{mV}, f=60$ $\mathrm{Hz}, \varphi=0^{\circ}$.

solutions. With HCl-HD solutions in the voltammetric cell, only roughly linear relationships in current $v s$. concentration plots were obtained for ametryn using all tested drop sizes. However, in the presence of $\mathrm{HCl}-\mathrm{HS}$ solutions in the voltammetric cell, no peaks were observed for drop sizes of $0.22 \mathrm{~mm}^{2}$ or smaller, and for drop sizes of 0.40 and $0.60 \mathrm{~mm}^{2}$ the stripping peaks were only observed for triazine concentrations starting from 1.53 and $0.87 \mu \mathrm{mol} \mathrm{L}{ }^{-1}$, respectively. Therefore, poor correlations between current and concentration $(r<0.90)$ were observed.

For concentrations of ametryn between 0.21 and 1.09 $\mu \mathrm{mol} \mathrm{L} \mathrm{L}^{-1}$ well shaped stripping peaks and good linear correlation coefficients ( $r>0.990)$ were only obtained for $\mathrm{HCl}$-water and $\mathrm{HCl}-\mathrm{HD}$ solutions as no trouble with the adsorption process and no saturation of the electrode surface occurred. However, as the electrosorption of organic compounds is the result of competitive adsorption between the organic substances and the ions of the supporting electrolyte, small and not quite defined voltammetric peaks were observed in presence of the HS solutions. In some cases the peaks disappeared completely, mainly for ametryn concentrations ranging from 0.21 to $1.09 \mu \mathrm{mol} \mathrm{L}{ }^{-1}$. This behavior was similar for all the triazines investigated.

\section{Voltammetry of triazines in water-ACN solution}

The well known practical difficulties of using organic solvents in electroanalysis to determine scarcely water- 
soluble compounds can be overcome by working with a proper water-organic solvent ratio so that changes in the configuration of the voltammetric systems become unnecessary. Some applications of this strategy can be found in voltammetric determinations using oil-water emulsions. ${ }^{43-46}$ The same principle was adopted here but without a proper formation of an emulsion, because the $\mathrm{ACN}$-phase separated from the saline solutions is quite soluble in the $\mathrm{HCl}$-water electrolyte. Instead, we used ACN because the saline species present in hemodialysis fluids were scarcely transferred from the aqueous to the $\mathrm{ACN}$ phase while the triazines were fully carried out.

As already pointed out, no speciation amongst the investigated triazines was possible by voltammetry, so it was important to detect them with the same sensitivity in order to simplify the calibration procedures. Differences on the peak heights at same concentration levels were observed amongst the triazines assayed directly in HD or HS solutions without the previous extraction step with $\mathrm{ACN}$. This result was somewhat unexpected because the presence of salts in voltammetric measurements is generally associated with beneficial aspects as the reduction of the solution resistance and the contribution of migration. However, in some cases the salt species can alter the kinetics on the electrode either by reacting with the products of an electrode process or by adsorbing on the electrode surface. ${ }^{47}$ In fact, we did not obtain acceptable calibration functions mainly for the triazines in the presence of HS solutions without ACN in the voltammetric cell. On the other hand, defined voltammetric peaks for the triazines and good calibration functions were obtained, decreasing drastically the saline content originated mainly from the HS solutions and adding $\mathrm{ACN}$ to the $\mathrm{HCl}$-water electrolyte. The presence of $\mathrm{ACN}$ in the voltammetric cell was suitable for analytical purposes as it did not intefere in the voltammetric determinations and showed a high efficiency to extract the analytes from the saline samples. The best peaks considering their symmetries, narrowness and signal to noise ratio were obtained with a 8:2 ratio between the volumes of $\mathrm{HCl}$-water and $\mathrm{ACN}$ in the voltammetric cell. ACN volumes higher than 2 with respect to the $8: 2$ ratio were related to increases on the baseline as the resistivity of the solution grew up. The same behavior was observed for all triazines investigated.

\section{Calibration in artificial HS samples}

Linear calibration graphs for ametryn, desmetryn, prometryn and terbutryn were obtained following the analytical procedures by using artificial HS samples spiked with only one triazine species and also with mixtures of them. The general calibration function $(\mathrm{n}=5) y=27.2( \pm$ $0.04) x+1.24( \pm 0.02)$ where $y$ is the stripping peak current in $\mathrm{nA}$ and $x$ the triazine concentration in $\mu \mathrm{mol} \mathrm{L}^{-1}$, was valid for the analyte concentrations ranging from 0.13 to $6.60 \mu \mathrm{mol} \mathrm{L}^{-1}(\mathrm{r}=0.997)$. The relative standard deviation $\left(\mathrm{s}_{\mathrm{r}}\right)$ calculated from five independent determinations using $0.44 \mu \mathrm{mol} \mathrm{L}^{-1}$ standards was $3.5 \%$. The limits of determination and detection were 0.07 and $0.03 \mu \mathrm{mol} \mathrm{L}^{-1}$, respectively. They were calculated according to the $10 \mathrm{~s}_{\mathrm{b}}{ }^{48}$ and the $3 \mathrm{~s}_{\mathrm{b}} / \mathrm{m}^{49}$ criteria, respectively, where $m$ is the slope of the range of linearity used and $s_{b}$ is the standard deviation $(n=5)$ of the background current that was estimated to be $0.3 \mathrm{nA}$.

Table 2 shows the results obtained from determination of the triazines in HS solutions and also the recovery in

Table 2. Determination of triazines and recoveries in commercial HS solutions by the adsorptive voltammetry

\begin{tabular}{|c|c|c|c|c|}
\hline HS sample ${ }^{a}$ & triazine added & $\begin{array}{l}\text { Concentration } \\
(\mu \mathrm{mol} \mathrm{L}-1)\end{array}$ & $\begin{array}{l}\text { triazine determined } \\
\quad\left(\mu \mathrm{mol} \mathrm{L} \mathrm{L}^{-1}\right)\end{array}$ & $\begin{array}{c}\text { Recovery } \\
(\%)\end{array}$ \\
\hline 01 & A & 0 & $\mathrm{nd}$ & - \\
\hline 02 & A & 0.44 & 0.42 & 95 \\
\hline 03 & $\mathrm{D}$ & 0 & $\mathrm{nd}$ & - \\
\hline 04 & $\mathrm{D}$ & 0.24 & 0.21 & 88 \\
\hline 05 & $\mathrm{P}$ & 0 & $\mathrm{nd}$ & - \\
\hline 06 & $\mathrm{P}$ & 0.21 & 0.22 & 105 \\
\hline 07 & $\mathrm{~T}$ & 0 & nd & - \\
\hline 08 & $\mathrm{~T}$ & 0.41 & 0.39 & 95 \\
\hline 09 & $\mathrm{~A}+\mathrm{P}+\mathrm{T}$ & $0.21,0.22,0.21$ & 0.61 & 95 \\
\hline 10 & $\mathrm{P}+\mathrm{D}+\mathrm{T}$ & $0.29,0.18,0.25$ & 0.70 & 97 \\
\hline 11 & $A+D+P+T$ & $0.17,0.18,0.29,0.21$ & 0.83 & 98 \\
\hline 12 & $\mathrm{P}+\mathrm{T}$ & $0.83,0.21$ & 0.96 & 92 \\
\hline 13 & $A+P$ & $1.07,0.41$ & 1.35 & 91 \\
\hline 14 & $\mathrm{D}+\mathrm{T}$ & $0.46,0.49$ & 1.00 & 105 \\
\hline 15 & $A+D$ & $0.34,0.56$ & 0.96 & 107 \\
\hline
\end{tabular}

a HS solutions: JP Indústrias Farmacêuticas, Salbego, B. Braun; ${ }^{\mathrm{b}}$ Values calculated from the calibration function (see text); nd: not detected; $\mathrm{s}$ ranging from 5.2 to $3.5 \%(\mathrm{n}=3)$; A: ametryn; D: desmetryn; P: prometryn; T: terbutryn. 
spiked solutions. Although the analytes were not found in the analyzed samples, the recuperation results showed that the method can be used to assay the triazines species in HS solutions used in hemodialysis procedures.

\section{Interferences}

Species with stripping peaks around $-1000 \mathrm{mV}$ can interfere with the determination of triazines. To test it some artificial HD samples were spiked with species detected as water contaminants in a long term study carried out during 4 years analyzing over 800 samples of dialysis water from 32 dialysis centers located in South Brazil..$^{50}$ It is important to emphasize that dialysis water should be free of contaminants. However, after the long term study it was possible to divide the dialysis water in 3 groups according to the contaminant levels, namely high $\left(>1.0 \mathrm{mg} \mathrm{L}^{-1}\right)$, medium ( 0.4 to $\left.1.0 \mathrm{mg} \mathrm{L}^{-1}\right)$ and low $\left(<0.4 \mathrm{mg} \mathrm{L}^{-1}\right)$. The main contaminants found in the high and medium concentration levels were nitrate, sulfate and fluoride. In the low level we found again the same anionic species and also aluminum in some samples. In the same way, commercial HS solutions should be free of contaminants but in a previous work ${ }^{51}$ we found $\mathrm{Cu}, \mathrm{Zn}, \mathrm{Pb}$ and $\mathrm{Cd}$ as contaminants at $\mu \mathrm{g} \mathrm{L}^{-1}$ levels in commercial HS solutions. The origin of this contamination was attributed to the salts used in the production of the HS solutions. So we tested the voltammetric method to assay the triazines with artificial HD and HS samples spiked with a ten-fold excess of the contaminants found in the dialysis water and also in the commercial HS solutions. The only species that interfered was the zinc ion due to its pre-concentration and stripping potentials, but the addition of EDTA to the voltammetric cell masked its interference.

\section{Conclusions}

The salting out effect originated in saline solutions used in hemodialysis procedures can be suitable to make acetonitrile scarcely soluble in them and able to quantitatively extract the investigated triazines. The acetonitrile phase dissolved in $\mathrm{HCl}$-water background electrolyte solution showed to be adequate to determine the triazines in hemodialysis fluids at low concentration levels on an HMDE. The speciation amongst the triazines, ametryn, desmetryn, prometryn and terbutryn was not possible but the general calibration function obtained, was suitable to detect the triazines as contaminants in hemodialysis solutions. The precision obtained (around $3.5 \%$ ) was good, taking into account the concentration levels used. The results obtained in recovery studies on spiked hemodialysis fluid samples show the suitability of the proposed method for the determination of these herbicides in this type of sample. EDTA can be used to overcome the interference of zinc ions.

\section{Acknowledgments}

The authors are grateful to CNPq, CAPES (ProDoc/ 2002) and FAPERGS for the financial support on the PSPPG project $\mathrm{n}^{\circ} 520771 / 99-0$.

\section{References}

1. Lippolis, M. T; Concialini, V.; Talanta 1988, 35, 235.

2. Mendez, J. H.; Martinez, R. C.; Martin, R. S.; Anal. Chem. 1986, 58, 1969.

3. Mendez, J. H.; Martinez, R. C.; Gonzalo, E. R.; J. Electroanal. Chem. 1988, 244, 221.

4. Li, C.; James, B. D.; Magee, R. J.; Electroanalysis 1990, $2,63$.

5. Benadikova, H.; Popl, M.; Jakobickova, V.; Collect. Czech. Chem. Commun 1983, 48, 2636.

6. Mendez, J. H.; Martinez, R. C.; Gonzalo, E. R.; Electroanalysis 1990, 2, 389.

7. Martinez, R. C.; Becerro, F.; Mendez, J. H.; Martin, P. G.; Electroanalysis 1990, 2, 567

8. Benadikova, H.; Kalvoda, R.; Anal. Lett. 1984, 17, 1519.

9. Smyth, M. R.; Osteryoung, J. G.; Anal. Chim. Acta 1978, 96, 335.

10. Barek, J.; Fogg, A G.; Moreira, J. C.; Zanoni, M. V. B.; Zima, J.; Anal. Chim. Acta 1996, 320, 31.

11. Lawrence, J. F.; Frei, R. W.; J. Chromatogr. 1974, 98, 253.

12. Coly, A.; Aaron, J. J.; Talanta 1998, 46, 815.

13. Ruiz, T. P.; Lozano, C. M.; Tomás, V.; Casajús, R.; Talanta 1996, 43, 193.

14. Kempter, C.; Berkhoudt, T. W.; Tolbol, G. C.; Egmose, K. N.; Karst, U.; Anal. Biochem. 2002, 372, 639.

15. Zhang, T. X.; Liu, H. Z.; Chen, J. Y.; Appl. Biochem. Biotechnol. 2000, 95, 163.

16. Grabchev, I.; Philipova, T.; Dyes Pigments 2000, 44, 63.

17. Weber, F.; Methods Mol. Biol. 2000, 140, 63.

18. Pacáková, V.; Stulík, K.; Príhoda, M.; J. Chromatogr. 1988, 442, 147.

19. Ward, T. M.; Weber, J. B.; Spectrochim. Acta, Part A 1969, 25, 1167.

20. Spencer, R. D.; Beggs, B. H.; J. Chromatogr. 1966, 21, 52.

21. Arranz, A.; Betoño, S. F.; Moreda, J. M.; Arranz, J. F.; Talanta 1997, 45, 417.

22. Skopalová, J.; Lemr, K.; Kotoucek, M.; Cáp, L.; Barták, P.; Fresenius' J. Anal. Chem. 2001, 370, 963.

23. López, M. A.; Ortega, F.; Domínguez, E.; Katakis, I.; J. Mol. Recognit. 1998, 11, 178. 
24. Chipperfield, J. R.; Non-Aqueous Solvents, Oxford University Press Inc.: New York, 1999, p. 8.

25. Mattson, A. M., Kahrs, R. A., Murphy, R. T.; Residue Rev. 1970, 32, 371.

26. Ismail, B. S.; Azlizan, B. A.; J. Environ. Sci. Health, Part B 2002, 37, 345.

27. Van Alphen, B. J.; Stoorvogel, J. J.; J. Environ. Qual. 2002, 31, 797.

28. Bhattacharjee, A. K.; Dureja, P.; J. Environ. Sci. Health, Part B 2002, 37, 131.

29. Páy, A.; Smith M. A.; Nagy, F.; Martón, L.; Nucleic Acids Res. 1988, 16, 8176

30. Wittenbach, V. A.; Koeppe, M. K.; Lichtner, F. T.; Zimmerman, W. T.; Reiser, R. W.; Pestic. Biochem. Physiol. 1994, 49, 72.

31. Higuera, M. J.; Galvín, R. M.; Mellado, J. M. R.; Montoya, M. R.; Electrochem. Commun. 2002, 4, 30.

32. Skopalová, J.; Lemr, K.; Kotoucek, M.; Cáp, L.; Barták, P.; Fresenius' J. Anal. Chem. 2001, 370, 963.

33. Higuera, M. J.; Montoya, M. R.; Galvin, R. M.; J. Electroanal. Chem. 1999, 474, 174.

34. Mckone, C. E.; Byast, T. H.; Hance, R. J.; Analyst 1972, 97 , 653.

35. Hayes, M. H.; Stacey, M.; Thompson, J. M.; Chem. Ind. 1967, $28,1222$.

36. Ludvik, J.; Zuman, P.; Microchem. J. 2000, 64, 15.

37. Skopalová, J.; Lemr, K.; Kotoucek, M.; Cáp, L.; Ondra, P.; Electroanalysis 1998, 10, 331.
38. Mendez, J. H.; Martinez, R. C.; Lopez, M. E. G.; Gonzalez, M. C.; Anal. Chim. Acta 1985, 176, 121.

39. Ignjatovic, L. M.; Markovic, D. A.; Veselinovic, D. S.; Besic, B. R.; Electroanalysis 1993, 5, 529.

40. Pedrero, M.; Calvo, V.; Villena, F. J. M.; Pingarrón, J. M.; Polo, L. M.; Analyst 1993, 118, 1405.

41. Carvalho, L. M.; Schwedt, G.; Electroanalysis 2001, 13, 596.

42. Sander, S.; Henze, G.; Electroanalysis 1996, 8, 253.

43. Pingarrón, J. M.; Reviejo, A. J.; Polo, L. M.; J. Electroanal. Chem. 1987, 234, 175.

44. Pingarrón, J. M.; Gordon, A.; Reviejo, A. J.; Polo, L. M.; Anal. Chim. Acta 1989, 216, 231.

45. González, A.; Pingarrón, J. M.; Polo, L. M.; Electrochim. Acta 1991, 36, 1573.

46. Reviejo, A. J.; Pingarrón, J. M.; Polo, L. M.; Electroanalysis 1992, 4, 111.

47. Bard, A. J.; Faulkner, L. R.; Electrochemical Methods, $2^{\text {nd }}$ ed., John Wiley \& Sons, Inc.: New York, 2001, p. 143.

48. ACS Committee on Environmental Improvement; Principles of Environmental Analysis, Anal. Chem. 1983, 55, 2210.

49. Hasebe, K., Osteryoung, J.; Anal. Chem. 1975, 47, 2412.

50. Nascimento, P. C.; Bohrer, D.; unpublished results.

51. Bohrer, D.; Nascimento, P. C.; Guterres, M.; Trevisan, M.; Seibert, E.; Analyst 1999, 124, 1345.

Received: February 4, 2003 Published on the web: August 14, 2003 